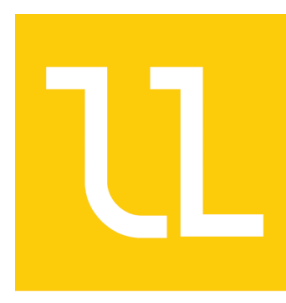

\title{
Betonút csak a Lajtán túl? (1. rész)
}

\author{
Erdélyi Attila ${ }^{1}$, Fenyvesi Olivér ${ }^{2}$, Gável Viktória $^{3}$, Gál Attila $^{4}$ \\ 1 BME Építőanyagok és Magasépítés Tanszék és Cemkut Kft., \\ 2 BME Építóanyagok és Magasépítés Tanszék, \\ ${ }^{3}$ Cemkut Kft., \\ ${ }^{4}$ Betontechnológia Centrum (BTC) Kft. \\ e-mail: erdelyi.attila33@gmail.com; fenyvesi.oliver@epito.bme.hu; gavelv@cemkut.hu; \\ gala@btclabor.hu
}

Kivonat Az egyre súrúbb nehézjármú-forgalom és a növekvố tengelysúlyok viselésére az aszfaltburkolatok az éghajlati melegedés hatásával tetézve - sok helyen már nem felelnek meg. Az Amerikai Egyesült Államok 45 államának tényleges pályázati árajánlatait elemezve igazolták, hogy az államok adott évi 200 millió dolláros költségvetéséból összesen több km út építhetố meg, ha a betonútépító iparág részesedése a költségvetésból mintegy 35-40\%-os (és az aszfalté igy "csak” 65-60\%), mert az így beálló egészséges versenyhelyzetben mind a beépített aszfalt, mind a beton egységára csökken. A helyes és gazdaságos arányt igazolják a tólünk nyugatra fekvố országok aszfalt/beton pályaburkolati viszonyszámai is (1. táblázat). Piaci versenyhelyzet nélkül a pályaburkolat kiválasztási eljárása értelmetlenné válik (Wathne L, ACPA). Vannak továbbá olyan esetek, amikor - az ártól függetlenül - a burkolatok gyors felújításához vagy cseréjéhez csak beton: "gyorsbeton" alkalmazható, pl. repülootéri kifutópályáknál, nagyforgalmú autóutaknál stb., amikor már 5 (zürichi repülótér)vagy 8-12-24 órás elzárás után a betonpályát át kell adni a forgalomnak. A gyorsbeton - a gyorsan szilárduló cement és a folyósító adalékszerek révén - már néhány óra vagy legföljebb 1 nap múlva (pl. M7-es út, táblacsere) eléri a terhelhetóséget jelentô kb. $20 \mathrm{~N} / \mathrm{mm}^{2}$ nyomó- és 4-5 N/mm² hajlítószilárdságot. Cikkünk következó, 2. részében további betonútépítési módokat tekintünk majd át (mosott beton, White Topping, azaz fehér/beton/szốnyegezés aszfalton vagy betonon, autópálya-építés újrahasznosított betonból, betonnyomsávos és egyéb betonanyagú mezó- és erdốgazdasági utak).

Kulcsszavak betonburkolat, beton kontra aszfalt, útburkolatfajta kiválasztása, piaci árverseny, globális felmelegedés, gyorscement, gyorsbeton

\section{Concrete roads only westward from Hungary?}

Abstract Asphalt pavements nowadays on many motorways do not correspond highly requirements caused by the continuously increasing number of heavy vehicles and axle loads. The global warming is also impairing the rideability of asphalt pavements under such conditions. An analysis of the actual bid data and unit prices for asphalt and concrete in 45 states of the USA is rendering the following data. From the same sum of budget less $\mathrm{km}$ length road can be built, if only one single type of pavement, i.e. asphalt is applied (and only such types of firms are involved in contracts), as compared to the case of a competitive market with concrete pavement building companies. If so, when sharing the budget with abt. $30-40 \%$ in favour of concrete pavement and such companies and so "only" the rest 70-60\% goes to asphalt road building, then due to the competition of the two types of road building companies both the unit price of asphalt and that of concrete will decrease significantly. USA experts (e.g. L. Wathne, ACPA) say that there is no equitable and meaningful pavement type selection process without a competitive market. The result of such a competitive market is also proved, when looking at the asphalt/concrete road ratio percent of West-Europeans countries (Tabl. 1.) Furthermore, there are cases of rapid pavement reconstruction necessities (eg. airport runways, busy motorways), where only the fast track paving concrete renders an acceptable solution as a traffic stop only for a few hours is allowed. Therefor a "fast concrete" attaining abt. $20 \mathrm{~N} / \mathrm{mm}^{2}$ compressive and $4-5 \mathrm{~N} / \mathrm{mm}^{2}$ flexural strength within these few hours must be used. The Part 2 of this paper will deal with other useful concrete pavement types (exposed aggregate surface concrete, White Topping, the use of recycled concrete in road building, agricultural concrete roads, etc.)

Keywords concrete pavement, concrete versus asphalt, selection of pavement type, market price competition, global warming, rapid cement, fast track paving 


\section{Dr. Erdélyi Attila}

(1933-) okl. mérnök (1956), ny. egyetemi docens, a múszaki tudomány kandidátusa. Kivitelezó a Máv Hídépítő Vállalatnál 1961-ig, majd tervezó a Vizitervnél 1963-ig. Tanársegéd, majd 1965-tól adjunktus dr. Palotás László professzor mellett a BME Építóanyagok Tanszéken. 1973-ban egyetemi doktor, 1984-ben a múszaki tudomány kandidátusa, 1985-tól egyetemi docens, 1991-tôl 1995-ig tanszékvezető. A FIP, majd fib Acélbizottságának volt magyar tagja, és a MAÚT tagja. 2003-ban Palotás-díjat kapott. Szakterületei: feszítő acélok relaxációja, feszítési veszteségek, adalékszerek, különleges sózás és fagyálló út-, híd-, vízépítési-, továbbá nagyszilárdságú-, tömeg- és gyorsbetonok, acélszálas betonok, nagymútárgyak betontechnológusa. Hazai és európai szabványosítás. Szakmérnöki és régebben mérnöktovábbképző, doktorandusz és angol nyelvú oktatás a fenti tárgykörökben.

\section{Dr. Fenyvesi Olivér}

(1981-) adjunktus, BME, okl. építómérnök (BME 2005), szerkezetépító PhD (BME 2012), múemlékvédelmi szakmérnök (2017), korróziós szakmérnök (2018), adjunktus a BME Építőanyagok és Magasépítés Tanszékén. Fő kutatási területei: betonok korai (autogén + száradási) zsugorodása, korai zsugorodási repedések közönséges és könnyúbetonokban, szálerôsített betonok, szálerôsített könnyúbetonok, könnyúbetonok tartóssága, önterüló könnyúbetonok, útbetonok, betonszerkezetek korróziója, épületdiagnosztika, épített örökség védelme. A Szilikátipari Tudományos Egyesület Beton Szakosztályának titkára, illetve Kő és kavics Szakosztályának tagja, a FIB (Nemzetközi Betonszövetség) Magyar Tagozatának tagja.

\section{Dr. Gável Viktória}

(1975-) kutatómérnök, Tanúsítási Iroda vezető, CEMKUT Kft., okl. elókészítéstechnikai mérnök (Miskolci Egyetem 1998), szerkezetépító betontechnológus szakmérnök (BME 2006), földtudományi PhD (Miskolci Egyetem, 2013), c. egyetemi docens (Miskolci Egyetem). Fó kutatási területei: klinkerek és cementkiegészítő anyagok ôrölhetősége; őrlési finomság értékelése; alternatív nyersanyagok cementipari felhasználhatósága; csökkentett klinkerhányadú cementek órlési technológiája, szemcseméret-eloszlása, minősége, alkalmazástechnikai tulajdonságai, csökkentett klinkerhányadú cementekból készült betonok teljesítóképessége, tartóssága. A Szilikátipari Tudományos Egyesület szakértóje (2012), az MSZT/MB 102 Cement és mész nemzeti szabványosító múszaki bizottság elnökhelyettese (2019).

\section{Gál Attila}

(1984-) okl. mérnök, Múszaki Földtudományi Kar, Környezeti eljárástechnikai és hulladékelőkészítéstechnikai szakirány (2009 Miskolci Egyetem), Nemesdy Ervin diplomadíj, Harsányi István tanulmányi ösztöndíj. Ellenórzố mérnök (2010-2018 Cemkut Kft.) Kutatási Terület: cementek szulfátduzzadásának mérése, cementek savállósági vizsgálatának fejlesztése. Laboratóriumvezető (2018-tól jelenleg is) Beton Technológia Centrum Kft.

\section{Kérdésfeltevés}

Az egyértelmú éghajlati felmelegedés, a nehézgépjármú forgalom és a tengelysúlyok növekedése, a súrú forgalmat akadályozó - a gyakoribb felújítások okozta - útlezárási és torlódási hátrányok miatt az aszfalttól a jó láthatóságú és tükröződésmentes felületek, a tartósan jól járható, kevesebb fenntartást igénylő betonpályák irányába kell eltolódnia az autópályák, gyorsforgalmi és megkerülő́ utak burkolatválasztásának.

Igazolni fogjuk, hogy ez múszakilag is és gazdaságilag is helyes megoldás (Asphalt Roads VS Concrete Roads, Liptay A,1966; Liptay, 2012).

A betonburkolat nem gyúlékony, ezért alagutakban és a hozzá vezetố szakaszokon sok országban kötelezó, benzinkutak környezetében mindenütt. A világos színe miatt jó fényvisszaveró, és ezért nagyvárosok hốségszigeteinek megszüntetéséhez (az egyébként még kedvezóbb zöldfelületek növelése mellett) az aszfaltot betonnal helyettesítik vagy azzal vonják be (White Topping vagy "fehérszốnyegezés"). Ugyanazt a megvilágítás erôsséget $\left(\mathrm{cd} / \mathrm{m}^{2}\right)$ kevesebb energiával lehet elérni. Jobb a jármúvek és személyek éjszakai láthatósága (Maier et al., 2016): és rövidebb a fékút a betonburkolatú utakon. A súrlódási együttható 7 év után is azonosnak tekinthetố a kezdeti értékekhez képest (Haider és Steigenberger, 2007, 3. ábra). Ezekre a kérdésekre a cikk 2. részben, amely az Útügyi Lapok őszi számában fog megjelenni, még visszatérünk.

A fentieken kívül a betonburkolatok széleskörúen ismert további előnyei:

- Alaktartó, nagy hómérsékleten sem keletkeznek nyomvályúk, a vizencsúszás előfordulásának veszélye kisebb.

- A hézagképzés a teherátadó vasalás révén (dübel) mára már megoldott, és a régi panaszok a táblák közti lépcsôképzôdés miatt ezzel teljesen megszúntek.

- Az aszfaltburkolatok élettartama általában 17-20 év, ezen belül 5-10 évenként felújítandók, ehhez képest a betonutak élettartama 30-40 év, 3-8 évente csak a hézagkiöntéseket kell javítani, nagy felújításra pedig átlagosan 25 év után van szükség.

- Az egyre növekvő́ tengelysúlyoknak és ezzel együtt járó nyíróeróknek a betonburkolatok, a 
nyári felmelegedések esetén is alakváltozás nélkül megfelelnek.

- A betonburkolatokon a gépjármúvek üzemanyag-fogyasztása és a károsanyag-kibocsájtása kisebb, mint aszfalt burkolatokon (nem „gyúrják" az aszfaltot és meleg időjárási viszonyok között kevésbé ragadnak) (Sommer, 2018, és Europave, 2009).

- A kezdetben kedvezóbb zajkibocsátású aszfalttal szemben a forgalmi zaj hosszú távon, betonburkolatokon kevésbé nó, mint az aszfalt változatoknál. Kétségtelen, hogy ma már léteznek zajcsökkentô vékonybevonatos aszfaltok, amelyek ennél jobb zajszint értékekkel jellemezhetôk (Breyer et al., 2009, 2. ábra).

- Fotokatalitikus úton az $\mathrm{NO}_{x}$ és karbonátosodással a beton a $\mathrm{CO}_{2}$-gázokat meg tudja kötni (Europave, 2009) bár az is igaz, hogy ez utóbbi esetén ugyanez a $\mathrm{CO}_{2}$-mennyiség a cementgyártáskor kibocsájtásra kerül, ami azonban más mértékú CEM I. tiszta portlandcement és más pl. CEM II. A/B-S útépítési kohósalak portlandcement esetén (Europave, 2009, 4. ábra).

- Gyorsbetonok alkalmazásával a pályazár 24, 12 órára vagy még rövidebb idôre csökkenthetố. A zürichi repülótér futópályáit 6 órás éjszakai repülési szünetek alatt újították fel (Schnyder és Hardegger, 2012).

- A friss beton egészség- és munkavédelmi rendszabályai nagyon egyszerúek az akár égési sebeket vagy egyéb egészségkárosodást is okozható forró aszfalthoz képet (The Shell Bitumen Handbook, p.24).

- A betonhoz csak hazai alapanyagokat használunk és így áringadozása csekély a külföldrôl behozott nyersolajéhoz képest (olajárrobbanás).

- A betonutak anyaga újrahasznosítható (Steigenberger et al., 2011 és e-UT 05.02.31 Útbeton betonhulladék újrahasznosításával Kausay T). Osztrák kísérletek szerint 10-15\% aszfalttartalom (amely régi betonpálya esetleges bevonásából származik) nem rontja a feltört régi betonburkolat újrahasznosíthatóságát). Elkészült az ezzel kapcsolatos Útügyi Múszaki Előírás átdolgozása is.

A betonburkolatokkal szembeni kihívások és hátrányok:

- a betonutak kivitelezése nagyobb technológiai fegyelmet és gyakorlott, jól képzett munkaerót igényel,

- költségesebb bedolgozógépek szükségesek a betonutak építéséhez,

- a betonutak javítása hosszabb idôt vesz igénybe és aprólékosabb, mint az aszfalt uta- ké, viszont a felújítások közötti időszak jóval hosszabb,

- a hézagokat rendszeresen karban kell tartani, de kb. ugyanolyan gyakran, mint amilyen az aszfaltpálya felújítási igénye,

- negatív imázs a médiában: "Mindig mindent lebetonoznak" (Jobb, ha leaszfaltozzák?),

- a vékonybeton szónyegezés (White Topping) igényesebb feladat, mint aszfaltréteggel való felújítás, de természetesen tartósabb,

- a beton pályaszerkezet megépítése energiaigényesebb, mint az aszfalt pályáé (Tóth, 2014) de a "környezeti lábnyom" szempontjából általában a betonpálya elónyösebb (Europave, 2009, 1. ábra).

\section{Helyzetfelmérés}

\subsection{Burkolatfajták}

Magyarországon az elsó sikeres betonburkolatot 1911 -ben építették Iglón (ma Szlovákia), amely 20 évig üzemben volt. Összehasonlításképp néhány más ország: Skóciában 1865-ben és 1872-ben; Franciaországban 1876-ban, Németországban 1880-ban, Ausztriában 1927-ben (Wallner és Steigenberger, 2008; Hulladéktároló telep kétrétegú betonburkolata) építettek elôször beton útburkolatot. Magyarországon az első világháború után 1927-1935 között az 1. számú fóutat 320 km hosszú betonburkolattal építették át. Ezek a burkolatok 50 év múlva is használatra alkalmasak voltak és az 60 éves fúrt magminták nyomószilárdsága 55 $\mathrm{N} / \mathrm{mm}^{2}$ volt (Liptay, 2017). Hazánkban az 1950-es évek elején még több, mint $1200 \mathrm{~km}$ betonburkolatú út volt (Gável és Gál, 2017). A 21 -es számú salgótarjáni fôút II. világháború elôtt készült betonburkolata még az 1980-as években is jól járható volt, az aszfaltos felújítás ezután kezdódött.

A KTI adatbázisa szerint a burkolatfajták megoszlása 1932-ben és a továbbiakban 1946-tól 2015-ig az 1. ábrán látható. Feltúnő, hogy a piros jelzésú betonburkolat a '60-as években mintegy 5 százaléknyi, - de 1980-ra, és azután 2015-ig a betonburkolatok gyakorlatilag eltúnnek az összesítésból. A Betonburkolatok címú könyv (Szerk. Keleti Magyar Betonburkolat Egyesület 2012, 2.10. ábra) szerint az utóbbi 20 évben 0,2-0,5\% a betonburkolatok aránya az egész magyar úthálózaton belül. Az országos közúthálózati nyilvántartás szerint 2018. december 31 -én a fóúthálózatból (8968km) az autópálya, autóút és ezek csomóponti ágai, továbbá az I. és II. rendú fóútvonalak hossza összesen 8902 km. Ebből betonpálya 93 km, azaz az összes elóbbi úthálózat 1\%-a. Versenyhelyzet tehát nincs. 


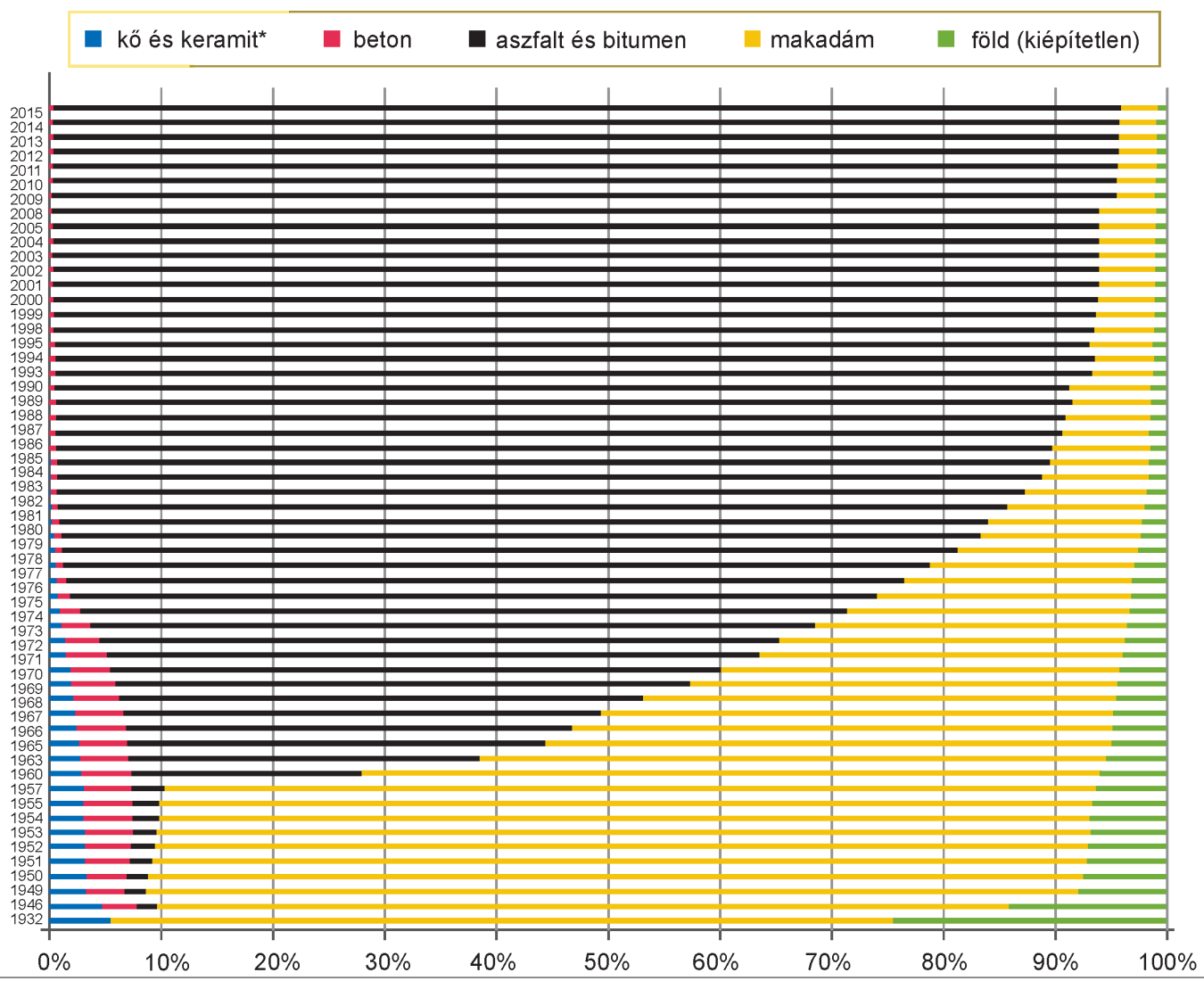

1. ábra. A magyar közúthálózat megoszlása burkolat típusa szerint (1932-2015) (KTI, 2015) http://www.kti.hu/trendek/a-magyar-kozuthalozat-megoszlasa-burkolat-szerint-1932-2015/ Letöltés dátuma: 2019. 05. 13.

\section{1. táblázat. Gyorsforgalmi utak burkolatfajtái [\%]}

\begin{tabular}{l|l|l|l}
\hline Ország & Aszfalt & Beton & Helyezés \\
\hline Belgium* & 30 & 70 & I \\
\hline Ausztria & 40 & 60 & II \\
\hline Németország & 50 & 50 & III \\
\hline USA & 50 & 50 & III \\
\hline Franciaország & 80 & 20 & IV \\
\hline Magyarország & $>97$ & $<3$ & $?$ \\
\hline
\end{tabular}

* Nagyrészt folytonosan vasalt betonburkolat (CRC)

Számunkra a gyorsforgalmi utak (autópálya, autóút) burkolati fajtáinak számaránya érdekes. A számarányokról a KTI tanulmánya szerint (Karsainé Lukács K és Bors, 2009) néhány mértékadó országban az 1 . táblázat adatai tájékoztatnak. Más forrásokban más számadatok találhatók, az évszámtól is függóen (Gável és Gál, 2017, [19]).

Késóbb látni fogjuk, hogy a betonburkolatok kb. 35-40\%-os és afölötti aránya mind a beton, mind az aszfalt ajánlati árát - a verseny miatt - lényegesen leszorítja. Egy külső szemlélő akár azt is megállapíthatja az 1. táblázat láttán, hogy úgy látszik "Magyarországon nem szeretnek tartós betonutat építeni." (Bakos, 2010).
A 2018. december 31.-i adatok szerint a magyarországi fóúthálózaton felület alapján összesen $2,15 \%$ betonburkolatú, a többi aszfaltos $(\mathrm{KSH}$, 2018). A 2000-es évek hazai betonpálya építési kísérleteiról lásd például Karsainé Lukács K. - Bors T. BETON 2007 12. sz. p8.

A hazai betonút építés megtorpanását az utolsó évtizedekben vélhetôen az M7-es betonpályának az elvártnál gyengébb viselkedése okozta. A pálya tábláit a kereszthézagokban nem kötötték össze teherátadó vasalással (dübel), noha - tudomásunk szerint - ez az eredeti terveken szerepelt, de késóbb „népgazdasági takarékossági okokból” ezt a tervból törölték azzal a magyarázattal, hogy a vakhézagok alatt az átrepedt betonban az adalékszemek összefogazódása (aggregate interlock) a táblák függóleges irányú eltolódását meg fogja akadályozni. Ezen kívül a betonburkolat alatt közvetlenül egy vékony bitumenes homokréteg volt, amely a fugakiöntô anyag elöregedése és a pályatáblák elmozdulása után a beszivárgó csapadék hatására kimosódott és ez a táblák további elmozdulását tette lehetôvé. A kivitelezô kimondottan - hiába - kérte a teherátadó vasalás alkalmazását (Betonburkolatok szerk. Keleti I. 2012)

Az olvasztósózás okozta lehámlást légbuborékképzó adalékszer alkalmazásával lehet a betonban megakadályozni. Az M7-esen vagy kevés, vagy 
semmi légbuborékképzót sem használtak, mert mindenáron a nyomószilárdságot akarták biztonságosan elérni, holott már akkor is köztudomású volt szakmai berkekben, hogy a lég(buborék) tartalom ugyan csökkenti a nyomószilárdságot, de biztosítja a fagyállóságot. Sajnálatos, hogy nem hivatkoztak az akkor egyébként mértékadónak tartott GOSZT szovjet szabványra, amely buborékképzôs betonra 10\%-os nyomószilárdságcsökkenést engedélyezett (a mostani EN 206, illetve az MSZ 4798 is eggyel kisebb szilárdsági osztályt enged meg légbuborékos betonra, azonos fagyállósági környezeti osztály pl. XF4 esetén).

\subsection{Hómérsékleti viszonyok}

Az utóbbi évtizedek hómérsékleti adatai szerint egyértelmú felmelegedés tapasztalható, ami a hóre érzékeny aszfaltpályák használhatóságát és állapotát - különösen a nyári, egymást követô hôségnapokon - rontja. Az utóbbi évtizedekben az előzóket lényegesen meghaladó éves hómérsékleti többletek láthatók a 2. ábrán; ennél érdekesebb volna a július-augusztusi, egymást követô hôségnapok tényleges hómérséklete és azok gyakorisága, mert ezek tapasztalat szerint növekednek, és ez az, ami az aszfalt igénybevehetôségét erôsen rontja. Megemlítjük, hogy egy újsághír szerint Skóciában a 30 ${ }^{\circ} \mathrm{C}$ feletti hóségben az aszfaltutak annyira megpuhultak, hogy egy sajtót bejárt kép szerint a burkolaton átsétálónak a cipóje beragadt az aszfaltba (Magyar Idók 2018. júl. 14. szombat, Jancsó Orsolya: "Hőhatás"; lásd még Gáspár L, 2010a és 2010b). Az aszfalt tehát kb. $10{ }^{\circ} \mathrm{C}-\mathrm{kal}$ lesz melegebb a napsugárzás hatására, mint a beton. A hómérséklet az aszfaltra azonban igen jelentôs hatású, például egy átlagos aszfaltkeverék -10 és $+30{ }^{\circ} \mathrm{C}$ hómérsékleti tartományban végzett merevségvizsgálata alapján
2. táblázat. Eltéró anyagú pályafelületek felmelegedése (Peyerl et al., 2016)

(https://www.met.hu/eghajlat/eghajlatvaltozas/megfigyelt valtozasok/Magyarorszag/ Letöltés dátuma: 2019. 05. 13.)

\begin{tabular}{l|c|l}
\hline A kísérleti mezó anyaga & Albedó & $\begin{array}{l}\text { Felületi hómérséklet } \\
\left({ }^{\circ} \mathrm{C}\right)\end{array}$ \\
\hline öntött aszfalt & 0,12 & $50 \pm 1$ \\
\hline aszfaltburkolat & 0,13 & $52 \pm 1$ \\
\hline beton pályalemez & 0,48 & $48 \pm 1$ \\
\hline$*$ fehérbeton (WT) & 0,57 & $41 \pm 1$ \\
\hline$* *$ világosbeton (WT) & 0,47 & $44 \pm 1$ \\
\hline közönséges beton (WT) & 0,48 & $43 \pm 1$ \\
\hline
\end{tabular}

WT = White Topping, betonszónyegezés (fehérszónyegezés), vé-

konybeton

* fehér cementtel

** pigmenttel fehérített közönséges cementtel

látszik, hogy a dinamikus modulusok jelentôs mértékben, kb. 28000 MPa és 2000 MPa értékek között változnak (Tóth, 2009), sốt növelve a vizsgálati hómérsékletet az aszfalt merevsége akár 1000 MPa alá is csökkenhet.

Általános tapasztalatként megállapíthatjuk tehát az aszfalt mechanikai tulajdonságai a hómérséklet emelkedésével romlanak, a betoné viszont nem.

\section{A pályaburkolat választás múszaki és gazdasági indokai}

\subsection{Múszzaki okok}

2004 óta a szakmában ismert a Breyer-féle diagram (vagy ismertnek kellene lennie), amely a burkolatfajta kiválasztását egyszerúsíti, lásd 3. ábra (Breyer és Steigenberger, 2006 és Breyer et al, 2009), illetve Breyer $G$. Entscheidungskriterien für den Bau

(b) nyár

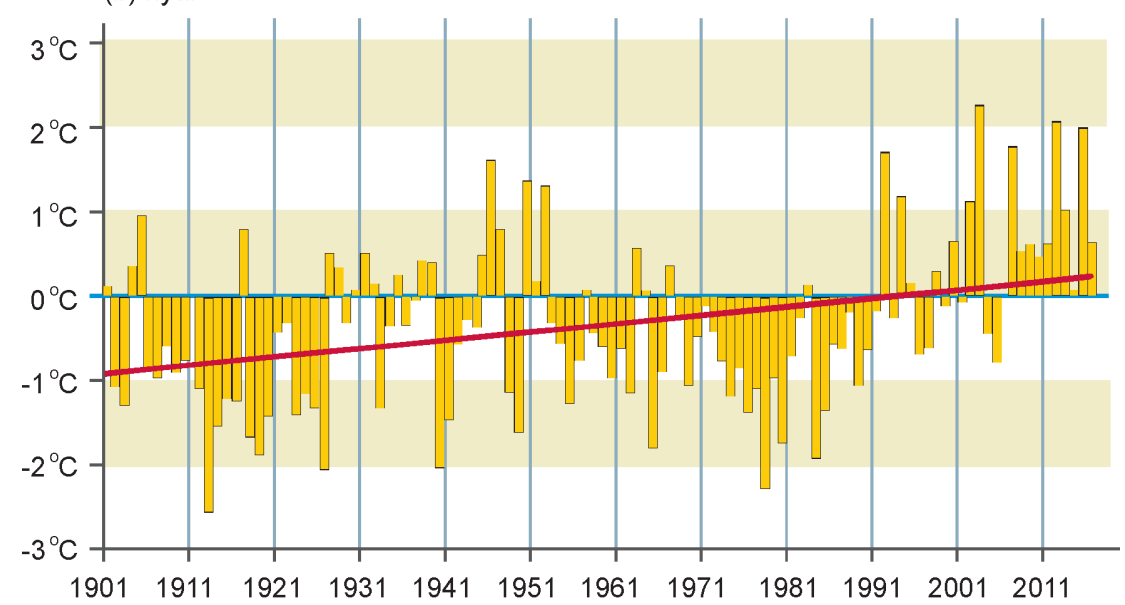

2. ábra. Az évszakos középhómérsékletek országos átlagainak anomáliái $\left({ }^{\circ} \mathrm{C}\right)$ 1901-2016 között. Az értékeket az 1981-2010 idôszakhoz viszonyították. (Homogenizált, interpolált országos átlagok alapján) 


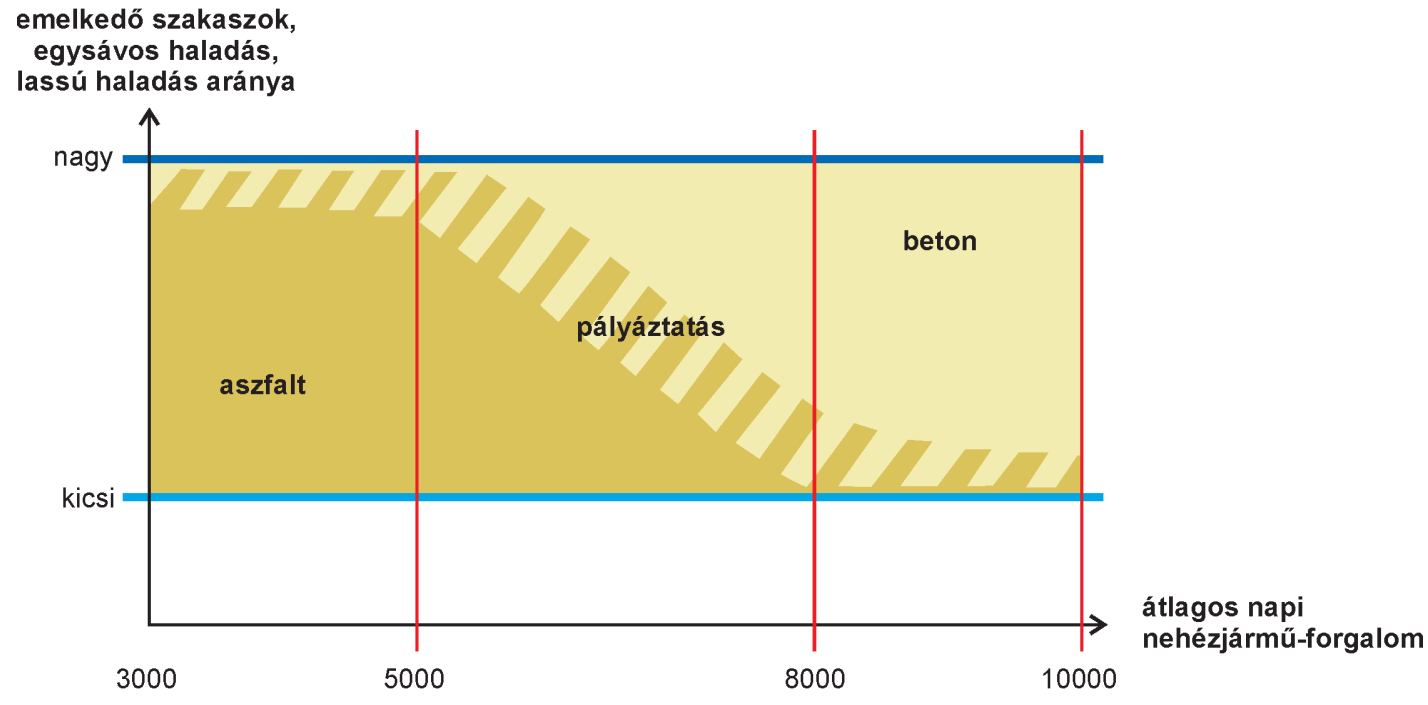

3. ábra. Döntési séma a burkolat kiválasztásához (Breyer et al, 2009)

von Betonfahrbahndecken in Österreich. Internationale Konferenz "Betonfahrbahnen 2004", Slavkov, Csehország)

A betonra esô választást - részben egymástól függetlenül is - kikényszerító múszaki tényezók:

- a napi nehézjármú áthaladási szám (pl. >8000),

- a pályaviszonyok: sok emelkedő, a lassú haladás aránya, sok íves szakasz, egysávon haladás, hosszú várakozások, határátkelők, most már beleértve a schengeni határokon is - ellenôrzés végett - megállított forgalmat.

- Ide írhatnánk harmadikként a területenként változóan nagy nyári hôségnapok számát is.

Mindezek a fékezés-gyorsítás (hosszirányú nyíróerók), az íves szakaszok (sugárirányú nyíróerók), üres járatban álló nehézgépjármúvek (közben olajcsöpögés?) révén mintegy "gyúrják" az aszfaltot és minél melegebb az aszfalt, annál inkább: mindezek hullámosodást, nyomvályúkat stb. okoznak. Mérsékelt számú nehéz gépjármú forgalom és/vagy kedvezóbb pályaviszonyok esetén az aszfalt és a beton közt versenynek kell döntenie. Németországban van egy olyan rendelkezés ("Allgemeine Rundschreiben"), hogy a pályázati kiírásban be- tonnak is szerepelnie kell, illetve vannak olyan esetek, amikor csak betonnal lehet pályázni.

Belátható, hogy vannak olyan esetek, amikor csak a múszaki szükségesség és igény dönt és ilyen esetekben csak betonpálya kerülhet szóba (pl. repülőterek, hernyótalpas katonai vagy egyéb jármúvek közlekedési útjai stb.). Ilyenkor a verseny a betonútépító cégek között, iparágon belül valósul meg. (Összehasonlításképpen: ha valahol rozsdamentes acélra van szükség, akkor hiába olcsóbb egy idôjárásálló vagy horganyzott acél, mindenképpen csak Cr-Ni ötvözésú acéllal lehet pályázni.)

A Lenti-Letenye közti 7538. sz. út 4×500 m-es kísérleti szakasz megépítésének és az élettartamra vonatkozó költségek elemzésének eredményét a 3. táblázat tartalmazza.

A „tényleges” organizációs feltétel az ottani valóságos viszonyokat szállítási távolságokat stb. veszi figyelembe, - az „azonos" organizációs feltétel pedig mindkét burkolati anyagra egy elképzelt egyformára szabott gyártási és építési körülményeket jelent. Az azonos körülmények közt, tehát a szokásos hézagaiban vasalt betonpálya - kissé alábecsült - 30 éves élettartamra 9\%-kal olcsóbb volt, mint a vizsgált aszfalt pályaszerkezet.

3. táblázat. A Lenti-Letenye közti 7538. sz. út kísérleti szakaszainak költségelemzése 30 évre (Karsainé Lukács K és Bors T, 2007; Karsainé Lukács K, et al., 2000)

\begin{tabular}{|c|c|c|c|c|}
\hline Kísérleti burkolat jellemzói & $\begin{array}{l}\text { Egységár a tény- } \\
\text { leges organizáci- } \\
\text { ós feltételek mel- } \\
\text { lett }\left(\mathrm{Ft} / \mathrm{m}^{2}\right)\end{array}$ & $\%$ & $\begin{array}{l}\text { Egységár az } \\
\text { azonos feltéte- } \\
\text { lek mellett } \\
\left(\mathrm{Ft} / \mathrm{m}^{2}\right)\end{array}$ & $\%$ \\
\hline 22 cm-es vastagságú, hagyományos betonburkolat, teherátadó hézagokkal & 9016 & 104 & 7920 & 91 \\
\hline 22 cm-es vastagságú, hézagokban vasalt, kimosással érdesítéett felületú betonburkolat & 9379 & 108 & 8231 & 95 \\
\hline 17 cm-es vastagságú, folytatólagosan vasalt, kereszthézag nélküli betonburkolat & 9445 & 109 & 8413 & 97 \\
\hline 21 cm-es vastagságú szfalt pályaszerkezet (4cm mZMA-12; 8 cm mK/F; 9 cm JU-35/F) & 8660 & 100 & 8660 & 100 \\
\hline
\end{tabular}




\subsection{Az árcsökkentó verseny}

Az ACPA (American Concrete Pavement Association, Washington DC.) 2013-ban kiadott egy tájékoztatót: „A burkolattípus kiválasztása: mi a kegkedvezóbb eljárás?”, azaz: "Pavement Type Selection: What is the Ideal Process?" címmel. (Wathne L, http://www.acpa.org/) Ez a tanulmány összefoglalja az AASHO és AASHTO ajánlásait, és az azóta kidolgozott elóírások és szoftverek említésével megadja a javasolt élettartam-költségelemzésének és a döntés elősegítésének módját, s ehhez folyamatábrát is ad (4. ábra).

A folyamatábrát nem részletezzük, mert ez kimondottan a pályáztatók, a burkolattípust kiválasztók és az LCCA-val (Life Cycle Cost Analysis, élettartam-költségelemzés) foglalkozó szakemberek számára lehet tanulságos (hazánkban pl. Gáspár L, Orosz Cs, Tánczos Lászlóné, Tímár A). A folyamatábra elsô „elágazási pontjához" a tanulmány hangsúlyozza, hogy a sikeres és költséghatékony döntés legfontosabb feltétele az iparágak közötti verseny,
- tehát lennie kell külön aszfalt és külön beton útépítési iparágnak és ezeken belül még versenyzó vállalatoknak is. Idézzük a tanulmány összefoglalójának utolsó bekezdését:

"Végezetül a burkolattípus kiválasztásának csak akkor van jelentósége, ha ez piaci verseny környezetében történik. A döntô tényezók közül semelyik másnak sincs olyan egyértelmú hatása, mint a versenynek az útügyi hatóságok azon képességére, hogy az infrastruktúra kihívásainak a szúkre szabott források esetében is meg tudjanak felelni. A gyorsforgalmi utak építésével foglalkozó hatóságok számára a verseny a legjobb lehetóség a mai gazdasági környezetben."

A verseny nélkülözhetetlenségét igazolja az USA 45 államából gyújtött ajánlati árak elemzése is. 5 éves időszakaszt véve alapul azok az államok (illetve az Állami Útügyi Minisztériumok, DOT, Department of Transport) járnak jól, ahol a beton-,

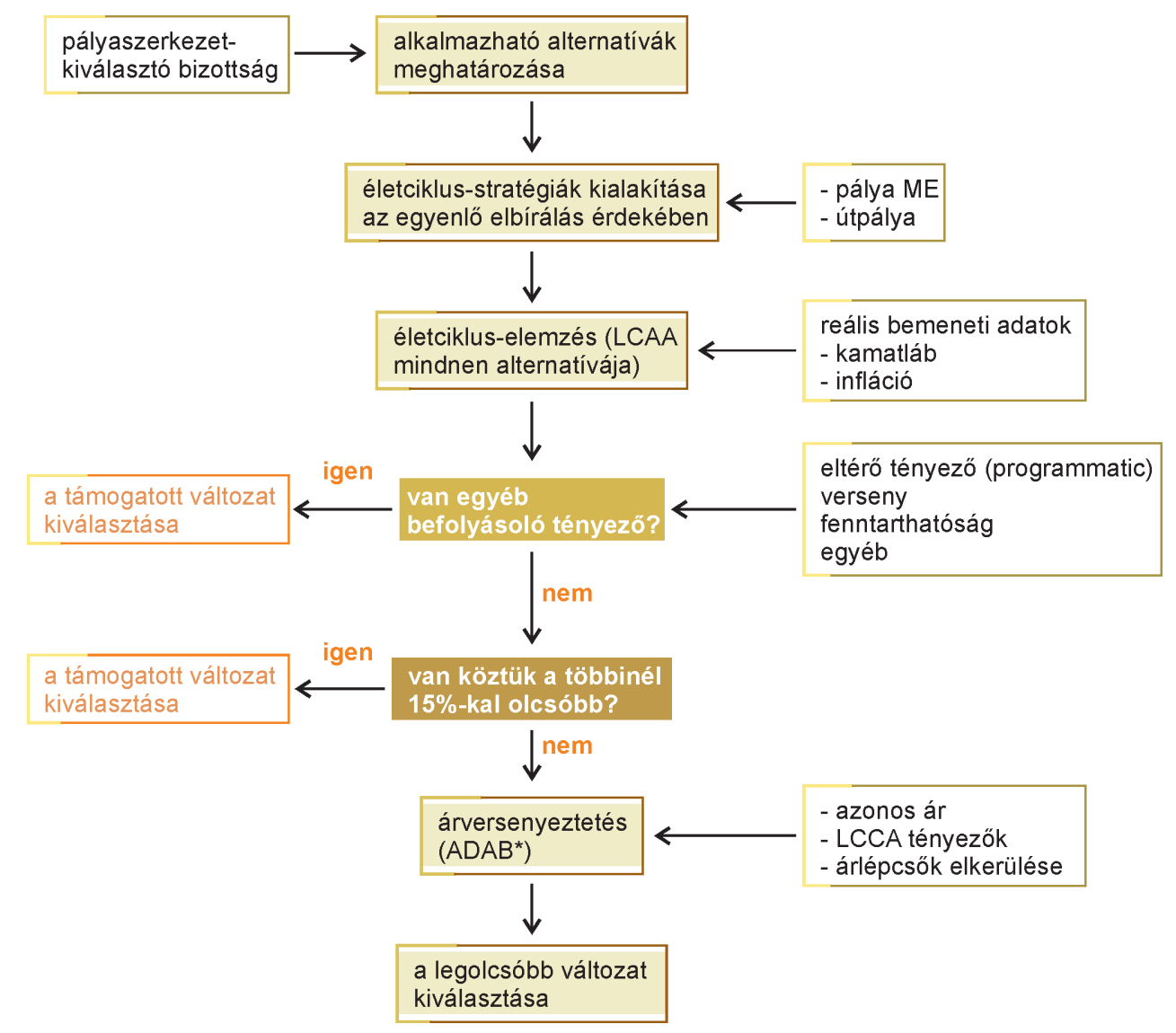

\section{4. ábra. A burkolattípus kiválasztásának folyamatábrája}

* $(\mathrm{ADAB}=$ Alternate Design Alternate Bid $)$

(Overview of the pavement type selection process)

(National Cooperative Highway Research Program NCHRP, Project 10-75, TRB 2011)

(További hozzáférési lehetőség az NCHRP 2011 TRB "Guide for Pavement Type Selection" irányelv és kiegészítései, FHWA (Federal Highway Administration) 2012 dec. 20. Washington DC. "Technical Advisory on Use of Alternate Bidding for Pavement Selection, T5040.38) 


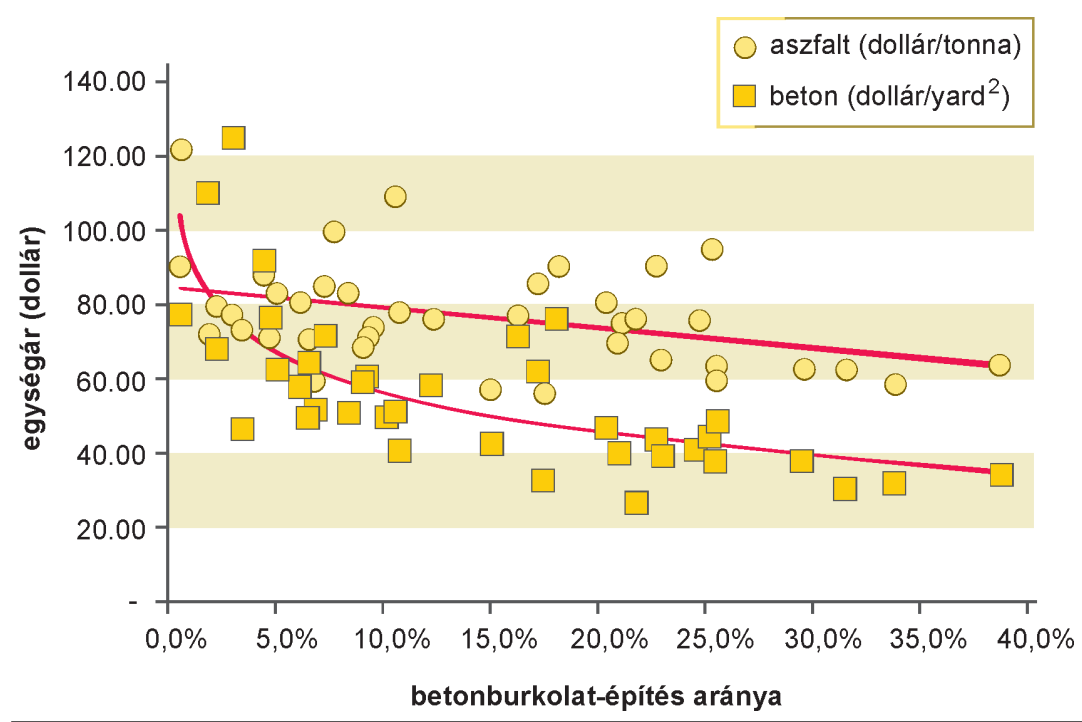

5. ábra. Burkolati egységárak \$-ban a betonburkolat építés növekvô aránya esetén $\left(1 \operatorname{yard}^{2}=0,84 \mathrm{~m}^{2}\right)$

illetve aszfalt iparágak részesedése kiegyenlített,és azok rosszul, amelyekben csak az aszfalt iparágnak van megrendelése. (A tanulmány úgy mondja, hogy a költségvetés szinte felrobban, "bang of the buck", "dollárrobbanás" áll be a versenyhelyzetben.) Ezt szemlélteti az 5. ábra és a 4a és b táblázat, a hivatkozott a Wathne L. féle tanulmányból.

Ha a beton részesedése az Útügyi Minisztériumok 5 éves ciklusa alatt csak néhány \%-nyi, akkor a 2013-as súlyozott ajánlati egységárak szerint a betonpálya yard ${ }^{2}$ szerinti költsége 80-120 \$, de az uralkodó aszfalt is drága: 80-120 \$/tonna. Ha van iparágak közötti verseny és a beton részesedése eléri az állami útépítési költségvetés 40\%-át (vö. a 1. táblázat), akkor a betonburkolat ára 40\$/yard2 alá megy, tehát az elóbbinek 1/3-a, és ugyanakkor az aszfalt árak is csökkenek - az elózónek 2/3-ára -, mert verseny van a két iparág között.

A 4a és b táblázatból kivehetô, hogy ugyanakkora 200 millió \$-os állami útépítési költségvetésból

4a táblázat. „Break-even” elemzés a burkolatépítésre szánt évi 200 millió \$-os költségvetésból (Wathne, 2013)

\begin{tabular}{|l|c|l|l|l|l|l|l|}
\hline Keret, millió \$ & $\begin{array}{l}\text { Beton aránya rá- } \\
\text { fordításból (\%) }\end{array}$ & $\begin{array}{l}\text { Aszfaltra fordí- } \\
\text { tott összeg } \\
\text { (millió \$) }\end{array}$ & $\begin{array}{l}\text { Aszfalt } \\
\text { egységára } \\
(\$)\end{array}$ & $\begin{array}{l}\text { Aszfalt mennyi- } \\
\text { sége } \\
\text { (tonna) }\end{array}$ & $\begin{array}{l}\text { Betonra fordított } \\
\text { összeg } \\
\text { (millió \$) }\end{array}$ & $\begin{array}{l}\text { Beton } \\
\text { egységára } \\
\text { (\$) }\end{array}$ & $\begin{array}{l}\text { Betonfelület } \\
\text { (yard })^{2}\end{array}$ \\
\hline 200 & 0 & 200 & 83,88 & 2384232 & - & - & - \\
\hline 200 & 5 & 190 & 81,24 & 2338829 & 10 & 66,94 & 149380 \\
\hline 200 & 10 & 180 & 78,59 & 2290382 & 20 & 56,13 & 356314 \\
\hline 200 & 15 & 170 & 75,94 & 2238558 & 30 & 49,81 & 602348 \\
\hline 200 & 20 & 160 & 73,29 & 2182989 & 40 & 45,32 & 882666 \\
\hline 200 & 25 & 150 & 70,65 & 2123255 & 50 & 41,84 & 1195137 \\
\hline 200 & 30 & 140 & 68,00 & 2058869 & 60 & 38,99 & 1538778 \\
\hline 200 & 35 & 130 & 65,35 & 1989266 & 70 & 36,59 & 1913236 \\
\hline
\end{tabular}

4b táblázat. A 4/a táblázat átszerkesztett változata (Pálya szélessége: 2·3,75 m forgalmi sáv + 3,00 m üzemi sáv = 10,5 m; aszfaltvastagság: 0,2 m; aszfalt sưrúsége $2400 \mathrm{~kg} / \mathrm{m}^{3}$ )

\begin{tabular}{|c|c|c|c|c|c|c|c|c|}
\hline $\begin{array}{l}\text { Aszfalt } \\
\text { mennyisége } \\
\text { (tonna) }\end{array}$ & $\begin{array}{l}\text { Aszfaltfelület } \\
\left(\mathrm{m}^{2}\right)\end{array}$ & $\begin{array}{l}\text { Aszfalt felület } \\
\left(\operatorname{yard}^{2}\right)\end{array}$ & $\begin{array}{l}\text { Aszfaltburko- } \\
\text { latú út hossza } \\
(\mathrm{km})\end{array}$ & $\begin{array}{l}\text { Betonfelület } \\
\left(\mathrm{m}^{2}\right)\end{array}$ & $\begin{array}{l}\text { Betonfelület } \\
\left(\text { yard }^{2}\right)\end{array}$ & $\begin{array}{l}\text { Betonburkola- } \\
\text { tú út hossza } \\
(\mathrm{km})\end{array}$ & $\begin{array}{l}\text { Összes bur- } \\
\text { kolt felület } \\
\left(\text { yard }^{2}\right)\end{array}$ & $\begin{array}{l}\text { Összes bur- } \\
\text { kolt felület } \\
\text { hossza }(\mathrm{km})\end{array}$ \\
\hline 2384232 & 4967150 & 4153170 & 473 & - & 0 & 0 & 4153170 & 473 \\
\hline 2338829 & 4872560 & 4074081 & 464 & 124901 & 149380 & 12 & 4223461 & 476 \\
\hline 2290382 & 4771629 & 3989690 & 454 & 297924 & 356314 & 28 & 4346004 & 483 \\
\hline 2238558 & 4663663 & 3899416 & 444 & 503640 & 602348 & 48 & 4501764 & 492 \\
\hline 2182989 & 4547894 & 3802619 & 433 & 738021 & 882666 & 70 & 4685285 & 503 \\
\hline 2123255 & 4423448 & 3698566 & 421 & 999287 & 1195137 & 95 & 4893703 & 516 \\
\hline 2058869 & 4289310 & 3586410 & 409 & 1286614 & 1538778 & 123 & 5125188 & 531 \\
\hline 1989266 & 4144304 & 3465166 & 395 & 1599709 & 1913236 & 152 & 5378402 & 547 \\
\hline
\end{tabular}


hány tonna aszfalt, illetve hány yard ${ }^{2}$ betonburkolat készíthetó, ha a beton részesedése a költségvetésben 0-35\%-ig növekszik. Ha pl. a beton részesedése a költségvetésból szerényen csupán 15\% (a sokkal kedvezóbb 35-40\% helyett), akkor a verseny nélküli 2384232 tonna aszfalt helyett kissé kevesebbet: 2238558 tonnát építenek be, - de a csökkenó 49,81 \$/yard ${ }^{2}$ egységárú betonból 602348 yard $^{2}$, azaz kb. 506 ezer $m^{2}$ betonburkolat is megépíthetó, ami majdnem "ingyen" van. Ez 10,5 m széles betonpályával (2·3,75m forgalmi sáv +3,00 m üzemi sáv) számítva 48 km. Azért csak "majdnem ingyen”, mert 2384 ezer tonna aszfalt (és a belóle készüló út) helyett csak 2238 ezer, azaz 6\%-kal kevesebb építhetó be aszfalt burkolatként, az említett hosszú élettartamú 48 km-es „ingyen" betonpályán kívül.

Az amerikai példa szerint a verseny (45 állam adatai alapján 40\%-os költségvetési betonpálya részesedés esetén (a nulla helyett) az aszfalt egységárát 100\%-ról 77\%-ra, a betonét pedig 66\%-ra, azaz mindkét egységárat csökkenti. Az egységár bizonytalanságok, vagyis a helyettesító görbe körüli szóródások kb. 20\%-nyi betonrészesedéstól kezdve szinte eltúnnek (5. ábra).

Ha tehát az államban a két iparág között erôs verseny van és a burkolatépítési stratégia és program is biztos és elórelátható, akkor ez mindkét anyagra alacsonyabb egységárakat eredményez. Ha a jól ismert döntési tényezók közül (forgalom, anyagok hozzáférhetôsége, idójárás, a burkolat hosszú idejú viselkedése, becsült költségek stb.) kifelejtik az egészséges versenyt, akkor a burkolat kiválasztási eljárás értelmetlenné válik. Ezt az ACPA tanulmányt a döntéshozóknak különösen is figyelmébe ajánljuk.

\section{Ajánlott betonút építési módok}

A továbbiakban - nagyrészt külföldi adatok alapján - a Magyarországon is követendó és követhetó alkalmazási módokat tekintjük át, amelyek múszakilag hasznosak és gazdaságosak lehetnek és lesznek, ha verseny is van.

\subsection{Gyorsbeton}

\subsubsection{M7-es autópálya táblacsere (Erdélyi et al, 2002)}

A gyorsbeton, azaz a 4-6-12-24 órás korban terhelhető, a hídépítésben feszíthetó, út- és repülőtéri burkolatok esetén a forgalomnak már átadható beton készítése semmilyen külön technológiát és tudnivalót nem igényel. A cementet, adalékszereket és adalékanyagot (ezek fajtáját és mennyiségét) és a v/c tényezốt kell úgy megválasztani, továbbá az utókezelést (a hidratációs hô benntartását és a párolgás megakadályozását) kell úgy megoldani, hogy a kívánt szilárdulási sebességet elérjük. Külön építésszervezési kívánalom, hogy a bedolgozó, szállító, áramfejlesztó stb. gépekból tartalék is legyen, mert itt a várakozás nincs megengedve. Mindehhez elózetes laboratóriumi munkák, szervezési terv és betontechnológiai utasítás (BTU) kell.

Az ÁKMI (Beruházó), a Betonútépító Vállalat (Kivitelezó, Liptay András), a Betonolith K+F Kft. (Technológia és labor: Erdélyi Attila, Szegó József, Máhr Géza) együttese kidolgozta az akkor 1997-ben az M7-es betonúton sérülés miatt cserélendónek ítélt tábláinak gyorsbetonnal való pótlását, - a tervezett 24+4-5 órás egy sávon közlekedő forgalomkorlátozással. A meglévố betonpályából magminták fúrása, a betonpálya feltörése, elszállítása, a tükör kiképzése és a teherbírás ellenôrzése kb. 4-5 órát vett igénybe. Az utolsóként bebetonozott szakasz volt 24 órás a forgalomba helyezéskor. A "régi $M 7$ " betonból vett magminták szilárdsága 45-70-64$60 \mathrm{~N} / \mathrm{mm}^{2}$, tehát bőven megfelelt.

Idézzük a BETON c. szaklap 1998. novemberi számában (16. oldal) megjelent rövid híradást - kis kiegészítéssel- Kiskovács Etelka szerkesztô tollából. Ez ott és akkor "Útjavítás betonnal az M7 autópályán" címmel jelent meg.

"1998. szeptember 30-án az M7 autópálya $83+200 \mathrm{~km}$. szelvényénél a balatonvilágosi benzinkutat követốen útjavítás folyt. Ez azért nevezetes esemény, mert a javításhoz gyorsan szilárduló betont használtak. A javítandó rész három táblából áll, 2 méter széles és $3 \times 5 \mathrm{~m}$ hosszú. A cserére azért volt szükség, mert túlsúlyos jármúvek a külsó perem mellett végigrepesztették a táblákat. A kereszthézagokat az elmozdulások megakadályozására a szokásos teherátadó vasalással (tüske, dübel) képezték ki. Az egyik táblánál múanyag szálat, a másiknál acél szálat is kevertek a bazalt adalékos betonba. Utóvizsgálatok során kiderülhet, hogy a PP száladagolás mennyire javítja a beton szilárdságát és tartósságát.

Elózetes laborkísérletek alapján dolgozták ki a betonreceptúrát, ennek lényege: a szokásosnál több, $420 \mathrm{~kg} / \mathrm{m}^{3}$ nagyon gyorsan szilárduló, de normálisan kötó cement, folyósítószer és légpórusképzó. Ezzel el lehet érni egy nap alatt kb. $35-40 \mathrm{~N} / \mathrm{mm}^{2}$ nyomószilárdságot és $4-5 \mathrm{~N} / \mathrm{mm}^{2}$ hajlítószilárdságot, ami fölötte van az osztrák elóírások szerinti 28 napos korra elóírt $5 \mathrm{~N} / \mathrm{mm}^{2}$ érték 3/4-ének $\left(3,75 \mathrm{~N} / \mathrm{mm}^{2}\right)$ és biztonságosan eléri a kb. $20 \mathrm{~N} / \mathrm{mm}^{2}$ nyomószilárdságot.

A kivitelezés reggel hatkor útelzárással az útpálya bontásával és a tükör elkészítésével kezdódött. A betont mixerkocsikkal szállították a 
helyszínre. Merülövibrátorral tömörítették, vibrogerendával és gumilemezes simítólapáttal simították. Kemény múanyag seprúvel bordázták keresztirányban (kép), majd kis idô múlva ráfújták az oldószeres párazáró szert és hốszigeteló paplannal letakarták. A beton beváltotta a hozzá fúzött reményeket, a forgalmat + 24 óra elteltével rá lehetett engedni (a beton ekkor kb. 22 órás volt). Bebizonyosodott, hogy a gyorsbetonból való útépítéshez van technológia, megfeleló alapanyag és tervezési tudás."

Ugyancsak a BETON havilap egy ezt követô számában "A kamionok is rámehetnek 24 óra után az új betonra az M7-esen" (A betonosok elsố sikere a 83-as km-kónél) c. cikk jelent meg. A gyorsbeton iránti érdeklődést mutatja, hogy "Fagyálló gyorsbeton" címen részletes beszámoló is található (Erdélyi A, 2002).

A tervezett táblacserénél 3 db 6 méter hosszú mezôt kellett kicserélni gyorsbetonnal - de a belsố sáv forgalma érdekében a külsố szélétôl számítva csak 2 méter széles sávokat bontottunk fel. A 6 méter hosszú lemezeket közepükön még egy-egy kereszthézaggal is megosztottuk, hogy kedvezóbb $2 \times 3$ méteres táblákat kapjunk. - Adódott a lehetôség,

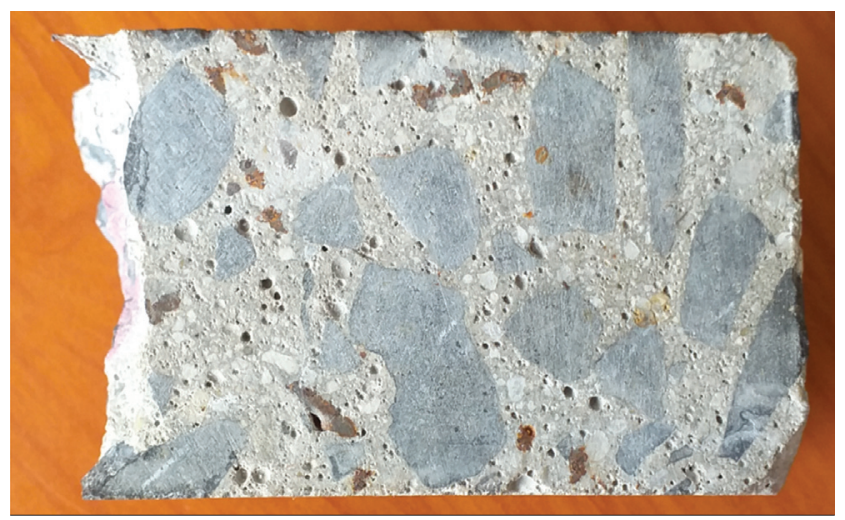

6. ábra. M7 gyorsbeton metszete (Fotó: Szentpéteri, 2019)

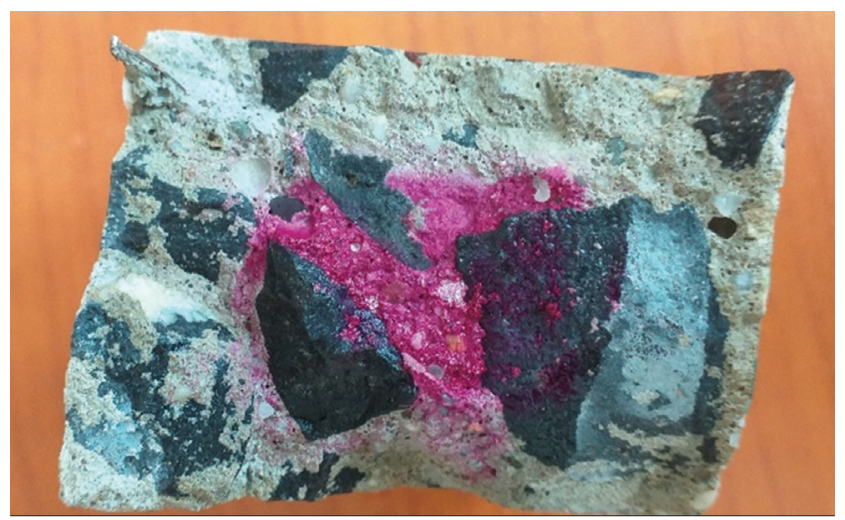

7. ábra. M7 gyorsbeton tört felülete (Fotó: Szentpéteri, 2019) hogy háromféle betont alkalmazzunk. Az egyik a szokásos légbuborékos útbeton volt (etalon), a másik PP szálas (Forta Fibre High Grade 190) beton, légbuborék képzố nélkül. Ennek oka, hogy a szakma és a kereskedelem úgy látta, hogy a vékony szálak mentén bentmaradó levegóréteg pótolja a buborékos betonban a légbuborékoknak köszönhetóen a kapillárisokat megszakító hatást és a szálak mentén bentmaradó víz pótlólagos utókezelést is jelent. A harmadik Harex SF 32-01, $35 \mathrm{~kg} / \mathrm{m}^{3}$ forgácsolt acélszálas beton volt, amelybe légbuborékképzốt is adalékoltunk. Ebból a betonból kifúrt próbatestekból készített vizsgálati hasáb fényképein (6. és 7. ábra) láthatók a légbuborékok (célszerúen 300-600 $\mu \mathrm{m}$ alattiak), valamint a szabadlevegón megrozsdásodott acélforgácsok. A tört keresztmetszetben a bazaltszemcse láthatóan jól tapadt és a karbonátosodás is (szürke színú kéreg) csak kb. 10-12 mm mélységú: tehát a vasvédelem is jó.

Az 1998-as akkori "gyorscement" választék idevágó adatai az 5. táblázatban találhatók. A mostani 2019-es cementválasztékát az 6. táblázatban adtuk meg, DDC adatok alapján. A két táblázat (1998. és 2019. évre vonatkozó) adatai azonosak. Emlékezetünk szerint 1998-ban a Váci Gyár még nem gyártott CEM I 52,5 N típusú cementet, csak CEM I 42,5 R típusút.

Az elốkísérletekhez az adalékszer, a PP- és acélszál osztrák szállítóival egyeztetve kétféle cementtel: váci CEM I 42,5 R és beremendi CEM I 52,5 N; v/c = 0,35 víz/cement tényezójú és kétféle gyártótól származó folyósító és buborékképzố adalékszer családdal D = $22 \mathrm{~mm}$-es bazaltadalékos $420 \mathrm{~kg} / \mathrm{m} 3$ cementadagolású betont készítettünk. E kísérletekben $70 \times 70 \times 250 \mathrm{~mm}$-es hasábok $I=200 \mathrm{~mm}$ támaszközú központos hajlításából számítottuk a hajlítószilárdságot és a félhasábokon mértük a nyomó- (test)szilárdságot $70 \times 70 \mathrm{~mm}^{2}$ felületen. Ezek eredménye a 8 . ábrán és a 7 . táblázatban látható.

\section{5. táblázat. Cementválaszték 1998}

Nagy kezdôszilárdságú hazai cementek tulajdonságai (CEM I. 52,5 - CEM I. 42,5 R)

Fajlagos felület $\left(\mathrm{cm}^{2} / \mathrm{g} 3700-3800\right)$

$\mathrm{C}_{3} \mathrm{~S}$ (tri-kalcium-szilikát) $>50 \%$

1 napos nyomószilárdság $\geq 18 \mathrm{~N} / \mathrm{mm}^{2}$

2 napos nyomószilárdság $\geq 30 \mathrm{~N} / \mathrm{mm}^{2}$

28 napos nyomószilárdság 60 N/mm

2 napos hajlítószilárdság 5,2-5,3 N/mm²

28 napos hajlítószilárdság 8,5-8,6 N/mm²

Kötés kezdete és vége (nem gyorskötô)

kezdete $\sim 2$ óra (120 perc)

vége $~ 3$ óra (180 perc) vagy több 


\begin{tabular}{|c|c|c|c|c|c|}
\hline & & & CEM I 52,5 N & CEM I 42,5 N & CEM II/A-S 42,5 N \\
\hline \multirow[t]{4}{*}{ Vác } & \multicolumn{2}{|l|}{ Blaine $\left(\mathrm{cm}^{2} / \mathrm{g}\right)$} & 4016 & 3510 & 3554 \\
\hline & \multirow{3}{*}{$\begin{array}{l}\text { Hajlító-nyomószi- } \\
\text { lárdság (MPa) }\end{array}$} & 1 nap & $4,9-21,1$ & $2,8-11,1$ & $2,3-8,8$ \\
\hline & & 2 nap & $6,0-30,7$ & $5,2-24,6$ & $4,6-20,7$ \\
\hline & & 28 nap & $8,4-65,0$ & $8,6-58,6$ & $8,6-56,3$ \\
\hline \multirow[t]{4}{*}{ Beremend } & \multicolumn{2}{|l|}{ Blaine $\left(\mathrm{cm}^{2} / \mathrm{g}\right)$} & 4166 & 3542 & - \\
\hline & \multirow{3}{*}{$\begin{array}{l}\text { Hajlító-nyomószi- } \\
\text { lárdság ( } \mathrm{MPa} \text { ) }\end{array}$} & 1 nap & $3,6-18,2$ & $2,2-10,8$ & - \\
\hline & & 2 nap & $5,7-30,4$ & $4,7-23,8$ & - \\
\hline & & 28 nap & $8,4-63,9$ & $8,7-58,2$ & - \\
\hline
\end{tabular}

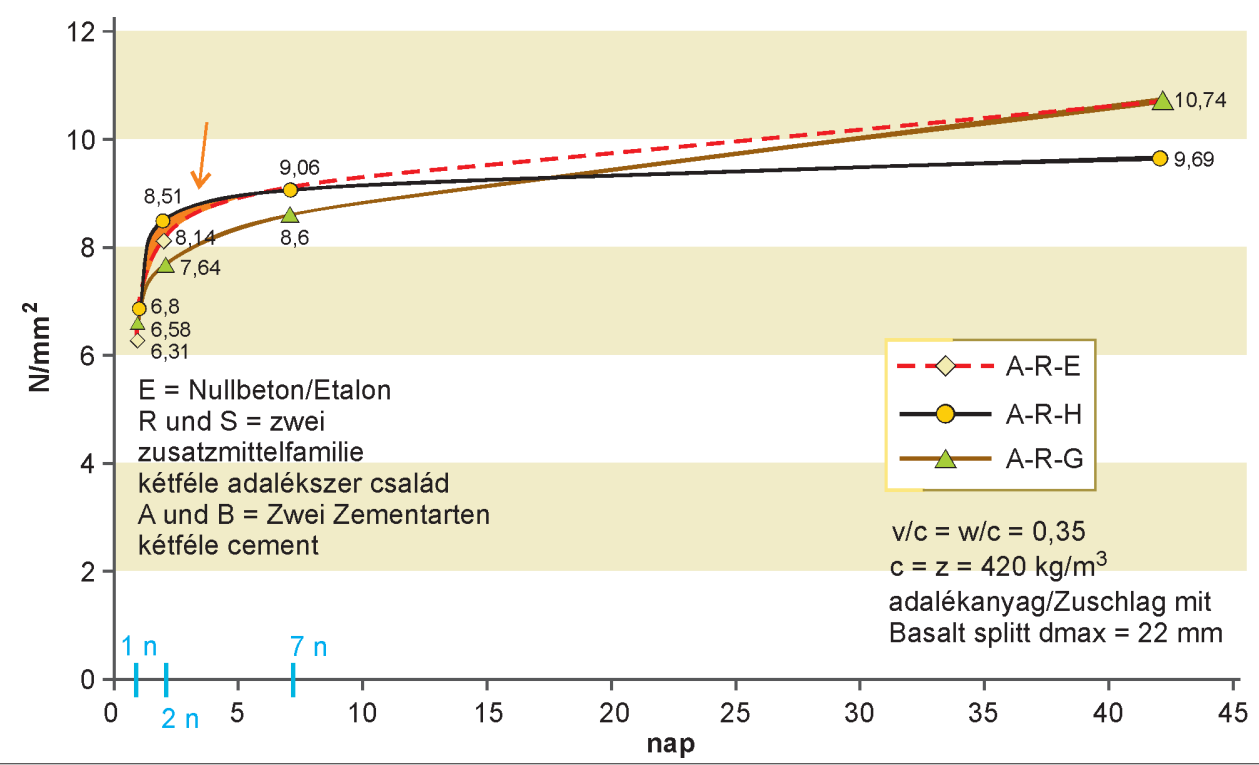

\section{8. ábra. Hajlítószilárdsági diagramok}

7. táblázat. M7 táblacsere elókísérlet II. (1997. júniustól). $7 \times 7 \times 25$ cm-es félhasábokon nyomó(test)szilárdság $\mathrm{N} / \mathrm{mm}^{2}$ (légtartalom egyformán kb. 5 térf. \%). *: 42 nap után laborlevegón tárolva, légszárazon törve, Betonolith $\mathrm{K}+\mathrm{F} \mathrm{Kft}$.

\begin{tabular}{l|l|l|l|l|l}
\hline \multirow{2}{*}{$\begin{array}{l}\text { Betonfaj- } \\
\text { ta }\end{array}$} & 1 & 2 & 7 & 42 & 900 \\
\cline { 2 - 6 } napos korban \\
\hline Etalon & 43,7 & 60,8 & 67,8 & 86,0 & - \\
\hline Harex & 46,7 & 61,7 & 74,9 & 86,2 & $96,4^{*}$ \\
\hline Forta & 42,2 & 53,9 & 62,8 & 85,8 & $95,4^{*}$ \\
\hline
\end{tabular}

Az elókísérleti 24 órás hajlító és nyomószilárdságok bóven felülmúlták a forgalomba helyezéshez szükséges értékeket.

Az 1998. szeptember 30./október 1-i táblacsere tényleges szilárdsági eredményei az útbetonokra elóírt próbatesteken a 9. ábrán, és 8. táblázatban találhatók. A 9. ábrán a Forta jelú „legjobb” múszálas beton nem volt buborékképzôs, így légtartalma sokkal kisebb és szilárdsága természetesen na- gyobb, mint a másik kettőé (a tényleges légtartalmak a 8. táblázat utolsó oszlopában találhatóak). Azonos (itt $0 \%$ ) légtartalomra átszámítva a nyomószilárdságokat 250 napos korra 150 mm-es kockán 96 $\div 107 \mathrm{~N} / \mathrm{mm}^{2}$ gyakorlatilag azonos eredményt kapunk (\# jelú adatok). A Harex acélszálas beton 24 órás értéke (8. táblázat és 9. ábra) nemcsak a nagyobb légtartalom miatt volt kisebb 24 órás korban, hanem azért is, mert Székesfehérvárról a betonüzemból ezt szállították utoljára és a délutáni melegben a betonüzem „kissé nehezen keverhetônek" találta (részben az acélszálak miatt), és ezért kötéskésleltetôt adagolt, hogy a munkahelyen „jól bedolgozhassák".

A 28 napos 150 mm-es kockák legkisebb szilárdsága (Harex) $61 \mathrm{~N} / \mathrm{mm}^{2}$, ami s=5 N/mm² szórást felvéve C40/50 szilárdsági osztályt jelent - jóval felülmúlva a szokásos autópályabetonokra elóírt CP-4/2,7 osztály (kb. C30/37) követelményeit -, ami természetes is a táblacserénél ténylegesen alkalmazott v/c=0,36 és CEM I 42,5 R esetén. Egyébként ezt a gyorsbetont 24 órás koránál elóbb is for- 


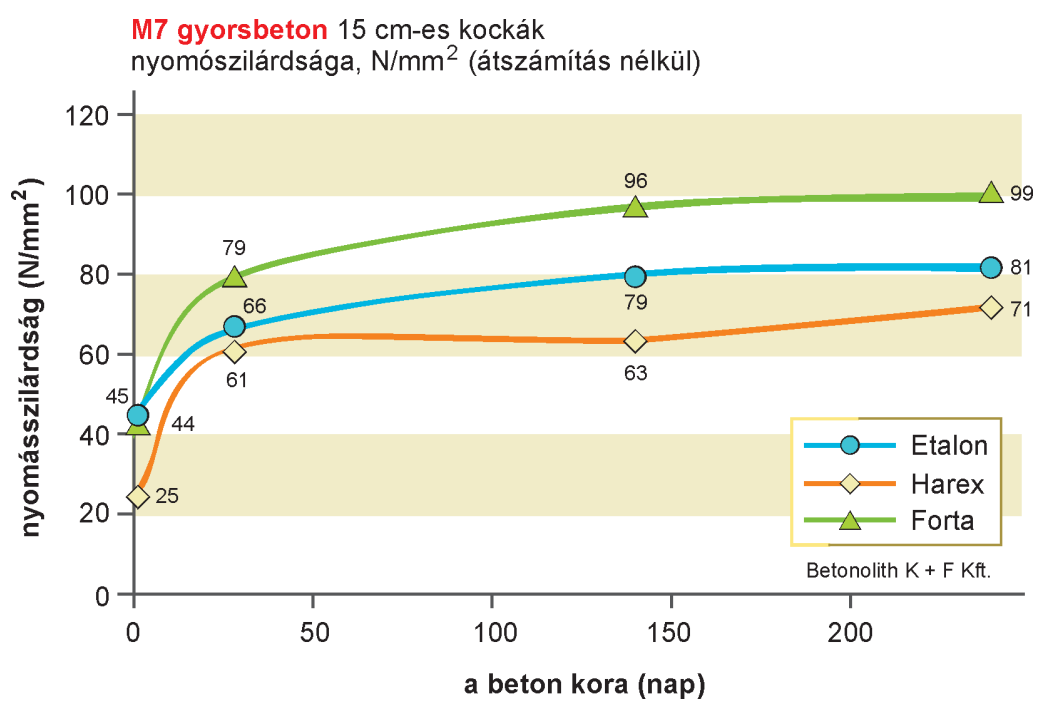

9. ábra. M7 gyorsbeton 15 cm-es kockák nyomószilárdsága, N/mm² (átszámítás nélkül)

galomba lehetett volna helyezni, a 24 órás szilárdsági adatokból visszakövetkeztetve.

Adalékanyag: az M7 táblacseréhez $\mathrm{OH}$ 0/4 mm homokot és 12/22 mm bazaltzúzalékot alkalmaztunk, - azaz kihagytuk a kedvezótlenebb szemalakú 5/12 mm-es bazaltzúzalékot (lépcsôs szemmegoszlás).

Tartósság. A 8. táblázat 180 napos oszlopában (*) alatt feltüntettük a 150-szer fagyasztott 150 mm-es kockák nyomószilárdsági eredményeit: eszerint fagylágyulás gyakorlatilag nincs. Ehhez hozzátesszük, hogy - fóleg a hídépítésben kedvelt "kockafagyasztáshoz" a vizsgálati szabvány 100 mm-es (érzékenyebb) kockát ír eló és ez a módszer az útbetonokra ma már nem mértékadó, mert azóta a peremes lehámlasztás („slab test") a referenciamódszer. Az itteni fagyállósági vizsgálatból tehát nem lehet különbséget tenni a háromféle beton viselkedése közt.

Az M7 autópálya táblacsere tapasztalatainak összefoglalása. Minden további gyorsbeton alkalmazásakor nincs szükség ilyen részletes elókísérletekre, mint amilyet az első alkalmazáskor végeztünk. Alapszabály: (a mostani cementválasztékból, lásd 6. táblázat) itt pl. váci CEM I 52,5 N, v/C 0,35 és bármilyen ismert jónevú cégtôl való folyósító és legbuborékképzó adalékszer (mindkettó ugyanattól a szállítótól), kb. 420 kg/m 3 cementadagolás és bazaltzúzalékos adalékanyag keverék (szemmegoszlás az ÚT elóírások szerint). Az elókísérlet lényege: próbakeverés, a konzisztencia és eltarthatóságának ellenórzése, a frissbeton légtartalom beállítása ( $D=22 \mathrm{~mm}$-hez $\mathrm{kb} .5 \mathrm{~V} \%$ ) és annak ellenórzése, hogy a légbuborékképzôszer szállítójának engedélyezési bizonyítványában szerepel-e, hogy az adott légtartalomhoz $t_{t} \leq 0,22 \mathrm{~mm}$ távolsági tényezót igazoltak. Próbatestekkel igazolni kell, a kívánság szerinti 6-12-24 stb. órás nyomóés hajlítószilárdságot, - utóbbit 150×150×600 mm-es gerendán mérve az MSZ EN 13877-1 szerint. (Lásd még a többi elóírást, Liptay, 2017 CEMBETON Útmutató 4.6.1. fejezetében.)

A szilárdulást ellenórzó próbatesteket a helyszínre érkezô gyorsbetonból kell elkészíteni hôszigeteló béléses fasablonban és ugyanúgy kell párazáróval lefújni és hôszigeteló paplannal takarni, mint a pályabetont.

\section{8. táblázat. Kockaszilárdságok 1-250 napig}

\begin{tabular}{|c|c|c|c|c|c|c|c|c|}
\hline Betonfajta & 24 órás korban & \multicolumn{2}{|c|}{28} & \multicolumn{2}{|c|}{180} & \multicolumn{2}{|c|}{250} & légtartalom o \\
\hline Etalon & 45 & 66 & $\{55\}$ & $\& 79$ & $\left({ }^{\prime} 72\right)$ & 81 & $\# 104$ & 5,60 \\
\hline Harex & 25 & 61 & $\{46\}$ & $\& 63$ & $\left({ }^{\prime} 60\right)$ & 71 & \#96 & 6,45 \\
\hline Forta & 44 & 79 & $\{70\}$ & $\& 96$ & (‘89) & 99 & $\# 107$ & 1,76 \\
\hline
\end{tabular}

\{\} 28 napos átm. $15 \times 20 \mathrm{~cm}$ magminták adatai

(') 3\%-os $\mathrm{NaCl}$ oldatban 150-szer fagyasztott kockák nyomószilárdsága

\# Átszámítva $0 \%$ légtartalomra

\& Ez légszáraz kb 88 (\#13); 77 (\#84); 108 (\#116) N/mm² lenne

a $\quad+1 \mathrm{~V} \%$ légtartalom kb. $4 \%$ szilárdság csökkenést okoz 


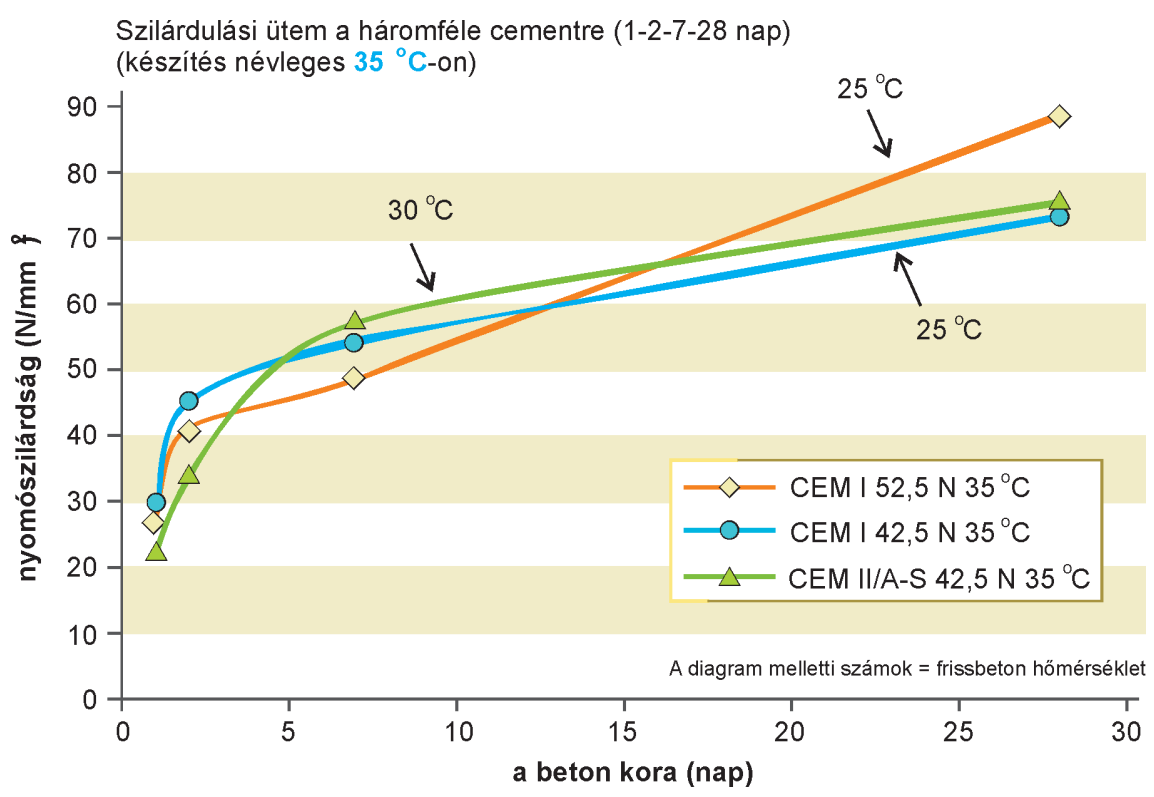

10. ábra. $25-30{ }^{\circ} \mathrm{C}$ tényleges kiinduló hómérsékletú betonok nyomószilárdsága

Nagy nyári hóségben (ami útbeton és betonút készítéséhez egyébként nem kedvezó) az említett CEM I cementek helyett CEM II/A-S 42,5 N (6-20\%) kohósalak-portlandcement is jó lehet gyorsbetonnak, ha a keverék hómérséklete „kényszerúségból” eléri a $30^{\circ} \mathrm{C}$-t. A 10. ábrából kitúnik (Betonolith $\mathrm{K}+\mathrm{F} \mathrm{Kft}$. kísérlete), hogy a ténylegesen $30{ }^{\circ} \mathrm{C}$ hómérsékletú CEM II/A-S 42,5 N cementtel 24 órás korban elérhetố a $22 \mathrm{~N} / \mathrm{mm}^{2}$ szilárdság, ami természetesen sem itt, sem az összes elóbb említett esetben nem pontosan 24 órás útelzárást jelent, mert a már említett elómunkálatok miatt az elzárás 4-6 órával hosszabb lehet. A kohósalak-portlandcement utószilárdulása (lásd 10. ábra) kedvezó. További - a külföldiekkel egyezó - tapasztalat még, hogy acélszálat alkalmazni csak akkor érdemes, ha a gyorsbeton dinamikus, ütközó hatásnak is ki van téve. (Az acélszál a betont szívóssá, nagy alakváltozásokra képessé teszi, törés nélkül, de a konzisztencia eltarthatóságát rontja és a felületképzést nehezíti.)

\subsubsection{A zürichi repülótér futópályáinak felújítása gyorsbetonnal: csúcsteljesítmény (Update 2012/03)}

Az előzó fejezet szerény feladatához képest az itteni $35 \mathrm{~cm}$ vastag beton futópályák tábláinak (alatta $55 \mathrm{~cm}$ cementstabilizáció, amely a teherbírást kis költséggel megnövelte) gyorsbetonnal való cseréjét az éjszakai forgalmi szünetben 23:30 és 5:30 között, azaz 6 óra alatt végezték, óriási gépesítéssel és szervezéssel. A betont 2,5 órás korában adták át a forgalomnak.

Update 2012/03. számából idézünk:
"A futópályák felújítása:

A zürichi repülótéren három fel- és leszállópálya van: ezek háromszög lakban helyezkednek el. A különbözó érkezési/indulási forgatókönyvek miatt a repülóüzemnek mindháromra szüksége van. A futópályák felújítására ezért csak éjszaka kerülhet sor. 20 éven át csak kisebb felületeket cseréltek ki gyorsan szilárduló betonnal. Kb. 10 éve kezdték meg az egészlemezes felújítást. Ma már éjszakánként akár 6 db $6 \times 6 \times 0,37$ m-es táblát is ki tudnak cserélni. Évenként, a nyári hónapokban kb. $1200 \mathrm{~m}^{3}$ gyorsbetont építenek be, ez kb. 100 db egyedi lemeznek felel meg. A gyorsbetonhoz legalább $21^{\circ} \mathrm{C}$ hómérsékletú frissbeton kell, hogy 150 perc alatt a 20 $\mathrm{N} / \mathrm{mm}^{2}$ szilárdságot elérje. Ezt a munkát tehát csak a nyári hónapokban lehet végezni. 24 óra múlva az ilyen beton $\mathrm{kb} .55 \mathrm{~N} / \mathrm{mm}^{2}$ nyomószilárdságú lesz, hajlító-húzószilárdsága pedig 5,5 $\mathrm{N} / \mathrm{mm}^{2}$. A lemezcserét a futópálya középsô, a gépekkel legjobban terhelt sávjában hajtják végre.

Belsố szervezés, logisztika

A betont egy repülôtér közeli keverôtelepen készítik. A beton a keveróvíz hozzáadása után 60 percig marad bedolgozható. A frissbeton adagok megkeverésének kezdetét ezért a munkahelyen zajló folyamatok állásának megfelelóen pontosan kell megrendelni. Az építésvezetó felelôs a rendelésért. További (a bedolgozás utáni) 90 perc múlva a beton szilárdságának legalább $20 \mathrm{~N} / \mathrm{mm}^{2}$-nek kell lennie. Ha ezt nem sikerül elérni, akkor a vészforgatókönyv lép életbe. (Az újonnan beépített betont fel kell törni és egy feketeburkolatú „ideiglenes tömésként" szolgáló lemezpótlást kell beépíteni.) 
Kivitelezés

- a futópálya lezárása 23 óra 30 perckor,

- kettốs mélyrávágás éjfélig,

- a beton feltörése bontókalapácsos gépekkel,

- a cementstabilizációs alsóréteg megtisztítása,

- alsó-hálóvasalás (dübelek) számára lyukfúrás a megmaradó betonba és a $d=32 \mathrm{~mm}, h=600$ mm-es vasak beragasztása,

- a felsó hálóvasalás $\left(8 \mathrm{~kg} / \mathrm{m}^{2}\right)$ elhelyezése,

- a gyorsbeton beépítése,

- seprús rovátkolás és az utókezeló szer felszórása,

- 60 percre rá letakarás hószigeteló paplanokkal,

- takarítás és szilárdságvizsgálat,

- a futópálya átadása a forgalomnak 5 óra 30 perckor.

Az éjszakánként $80 \mathrm{~m}^{3}$ gyorsbeton készítéséhez és beépítéséhez hatalmas géppark (állóeszköz érték 2,5 millió CHF, azaz 2 millió Euró) és egy 20 fốs csapat szükséges, amelyik különlegesen ki van képezve a gyorsbeton készítésére és beépitésére."

(Marco Schnyder, Basler \& Hofmann AG, Zürich, E-Mail: marco.schnyder@baslerhofmann.ch;

Daniel Hardegger, Implenia Bau AG, Zürich, E-mail: daniel.hardegger@implenia.com)

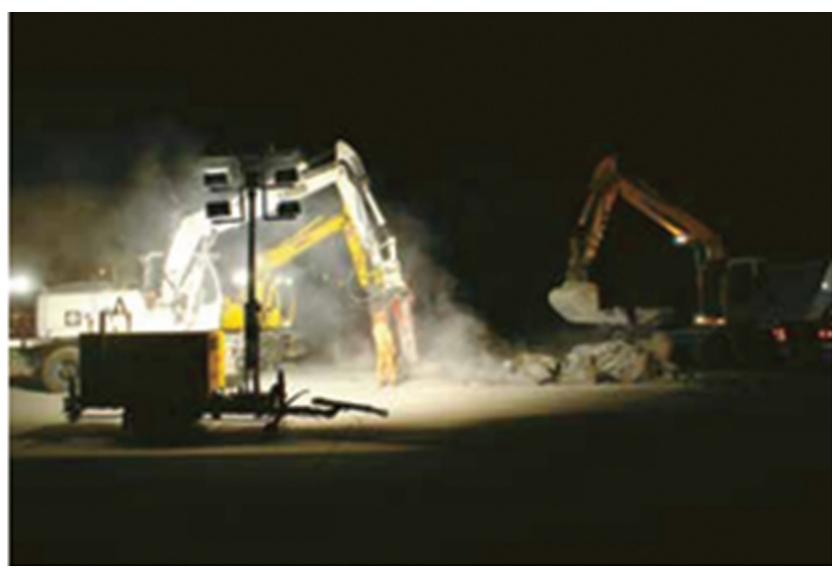

Éjszakai üzemszünet alatti burkolatfeltörés

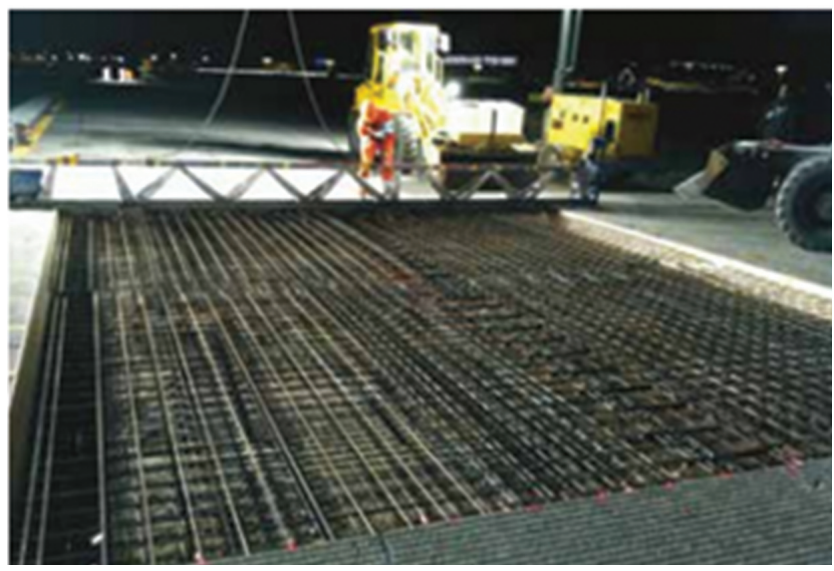

A gyorsbeton lemez számára elhelyezett hálóvasalás

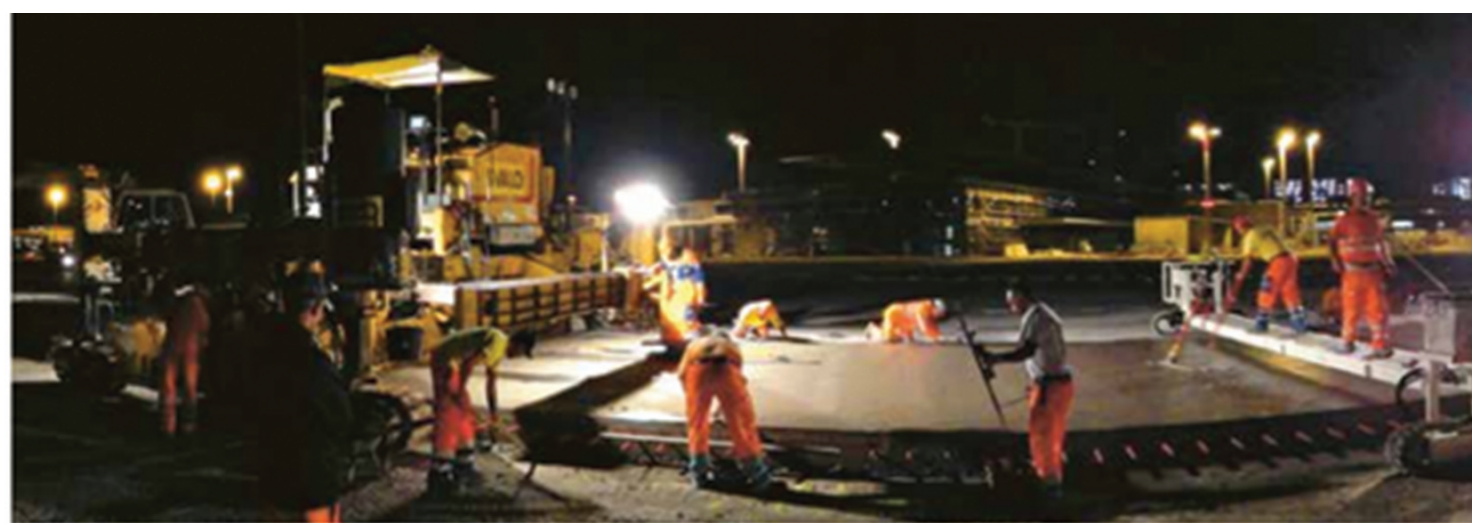

Gépi betonbedolgozás csúszózsalus finiserrel

11. ábra. A zürichi repülótér futópályáinak felújítása gyorsbetonnal (Schnyder és Hardegger, 2012)

\section{Összefoglalás}

Az egyre súrúbb nehézjármú-forgalom és a növekvô tengelysúlyok viselésére az aszfaltburkolatok az éghajlati melegedés hatásával tetézve - sok heIyen már nem felelnek meg. Az Amerikai Egyesült Államok 45 államának tényleges pályázati árajánlatait elemezve igazolták, hogy az államok adott évi 200 millió dolláros költségvetéséból összesen több km út építhetô meg, ha a betonút épító iparág részesedése a költségvetésból mintegy 35-40 \%-os (és az aszfalté így „csak” 65-60), mert az így beálló egészséges versenyhelyzetben mind a beépített aszfalt, mind a beton egységára csökken.

A helyes és gazdaságos arányt igazolják a tôlünk nyugatra fekvó országok aszfalt/beton pályaburkolati viszonyszámai is (1. táblázat). Piaci versenyhelyzet nélkül a pályaburkolat kiválasztási eljárása értelmetlenné válik (Wathne $L, A C P A$ ).

Vannak továbbá olyan esetek, amikor - az ártól függetlenül - a burkolatok gyors felújításához vagy cseréjéhez csak beton: "gyorsbeton” alkalmazha- 
tó, pl. repülótéri kifutópályáknál, nagyforgalmú autóutaknál stb., amikor már 5 (zürichi repülótér) vagy 8-12-24 órás elzárás után a betonpályát át kell adni a forgalomnak. A gyorsbeton - a gyorsan szilárduló cement és a folyósító adalékszerek révén - már néhány óra vagy legföljebb 1 nap múlva (pl. M7-es út, táblacsere) eléri a terhelhetôséget jelentó kb. $20 \mathrm{~N} / \mathrm{mm}^{2}$ nyomó- és $4-5 \mathrm{~N} / \mathrm{mm}^{2}$ hajlítószilárdságot.

Cikkünk folytatásában, a 2. részben néhány betonút építési módot (fehérszőnyegezés, azaz White Topping, mezó- és erdógazdasági utak, kombinált aszfalt + beton alkalmazások, újrahasznosítás stb.) fogjuk áttekinteni, és kitérünk néhány részletkérdésre: fényviszonyok és megvilágítás, felületi érdesség és felületkiképzési módok (mosott beton), fékút, zajkibocsátás stb.

\section{Köszönetnyilvánítás}

A Szerzók hálásan köszönik Szentpéteri Ibolyának (okl. építómérnök, doktorandusz, BME Út- és Vasútépítési Tanszék) az adatbeszerzés, a táblázatok összeállítása, az ábrák kiegészítése, és az irodalomjegyzék gondozása terén kifejtett pontos munkáját. Köszönik továbbá Dr. Kausay Tibor c. egyetemi tanár segítségét nemrég elhunyt neves kollégánk: Dr. Liptay András betonutakra vonatkozó szakirodalmi tevékenységének feltárásában.

\section{Irodalom}

Apshalt Roads VS Concrete Road: https://www.youtube.com/watch?v=IZJNgCPN4Ek Letöltési idő: 2019. 05. 10.

Bakos A. Beton kontra aszfalt. Dél Magyarország, Szeged Hírei, 2010. február 8.

Breyer G, Litzka J, Steigenberger J. A betonút - idótálló építési mód, biztos jövóvel; Update 2009/09/3.*

Breyer G, Steigenberger J. Betonburkolatok nemzetgazdasági szempontból; Update 2006/3.*

Erdélyi A. Fagyálló gyorsbeton in Beton- és vasbeton szerkezetek védelme, javítása és megerôsítése II. (szerk. Balázs Gy). Múegyetemi Kiadó 2002; 7.2. fejezet, p.84.

Erdélyi A, Kádár O, Németh I, Máhr G.(2002): Táblacsere gyorsbetonból az M7 autópálya $83+200$ km szelvényében in Beton- és vasbeton szerkezetek védelme, javítása és megerôsítése II. (szerk. Balázs Gy) Múegyetemi Kiadó 2002; 8.15. fejezet p.309.

Europave kiadvány (2009): Concrete Roads: a Smart and Sustainable Choice; 2009. 09. https://www.eupave.eu/ Letöltés ideje: 2019. 05. 13.

e-UT 05.02.31:2008 Útbeton betonhulladék újrahasznosításával

Gáspár L. Betonburkolatokkal kapcsolatos újdonságok. BETON $2007 ; 2: 22-23$

Gáspár L. Éghajlatváltozás és a hazai útügyi szabályozás; Közlekedésépítési Szemle 2010a; 60(10):1-9.
Gáspár L. Felkészülés az éghajlatváltozás közúti közlekedési kihívásaira. Közlekedéstudományi Szemle, 2010b; $12: 13-20$

Gável V, Gál A. Beton versus aszfalt. CEMKUT tanulmány. 2017.

Haider M, Steigenberger J. Mosott beton felületek hosszú távú viselkedése akusztikai szempontból; Update 2007/1.*

Internationale Fachtagung 2005 «Betondecken aus volkswirtschaftlicher Sicht». Vortragsband, 2005

Karsainé Lukács K. Betonburkolatok alkalmazása fenntartásban és felújításban. KTI 2009. évkönyv, p. 233.

Karsainé Lukács K, Bors T. Betonburkolatú kísérleti útszakaszok építése és állapot-megfigyelése 1 . rész: Letenye - Lenti összekötó út; BETON; 2007; 12:8.

Karsainé Lukács K, Bors T. KTI tanulmány, 2009.

Karsainé Lukács K, Liptay A, Táskai Andorné. Kísérleti útszakaszok a 7538. sz. Letenye-Lenti közti nehézfogalmi, úton, Közúti és Mélyépítési Szemle, 2000/5

Keleti I (szerk.). Betonburkolatok. Magyar Betonburkolat Egyesület, 2012.

Liptay A. Cembeton Útmutató; Magyar Cement-, Beton- és Mészipari Szövetség, 2017.

Liptay A. Betonutak fejlesztése és építése az utóbbi 60 évben Magyarországon. http://www.betonopus.hu/notesz/ liptay-betonutak-60.pdf; Letöltési dátum: 2019. 05. 13.

Liptay A. A betonútépítés helyzete és jövôje Magyarországon, Közúti Közlekedési- és Mélyépítéstudományi Szemle, $1966 ; 11: 416-426$.

Liptay A: Fejezetek a betonútépítés fejlődéséról (szerk. Keleti I. Betonburkolatok). MBBE, 2012, 15-21, 277-283.

Maier G, Peyerl M, Krispel S. TunnelHELL („AlagútVILÁGOSAN”) Az alagutak betonanyagú útpályáinak hatása: növekvő biztonság és energiatakarékosság egyszerre. Update 46; 2016. november*

Peyerl M, Krispel S, Weihs P, Maier G. Városi közlekedési felületek - legkedvezóbb beton a városbelsók számára. Update 44/2016*

Schnyder M, Hardegger D. A zürichi repülótér pályáinak felújítása, Update 2012/12/3*

Sommer H. Betonstraßen im Wandel; Zement + Beton, 2018; 2:5-8.

Steigenberger J, Eisner H, Marchtrenker S. A beton újrahasznosítása az útépítésben; Update 11/1, 2011.*

Tóth Cs. (2014): Sustainable pavement: környezettudatos és energiatakarékos útpályaszerkezetek. (Szerk. Keleti I. Hosszú élettartamú útpályaszerkezetek.) Budapest, Magyarország: Konferencia Iroda Bt, 2014; 1-9, 4, 9.

Tóth Cs. Aszfaltkeverékek viszkoelasztikus viselkedésének jellemzése Huet-Sayegh-modellel. Közlekedésépítési Szemle, 2009 Augusztus; 59:(8)6-12.

Wallner R, Steigenberger J. Betonburkolat a városi úthálózaton - egy megkerülhetetlen tényezó; Update 2008/1

Wathne L. Pavement type selection: What is the ideal process? http://www.acpa.org/ letöltés dátuma: 2019. 05. 13.

Wien, 2005;

www.zement.at (http://www.zement.at/page.asp?c=158) Letöltési dátum: 2019. 05. 13.

*Az Update kiadványok a cembeton.hu honlapon megtekinthetók és letölthetók. 